\title{
Information Sheet
}

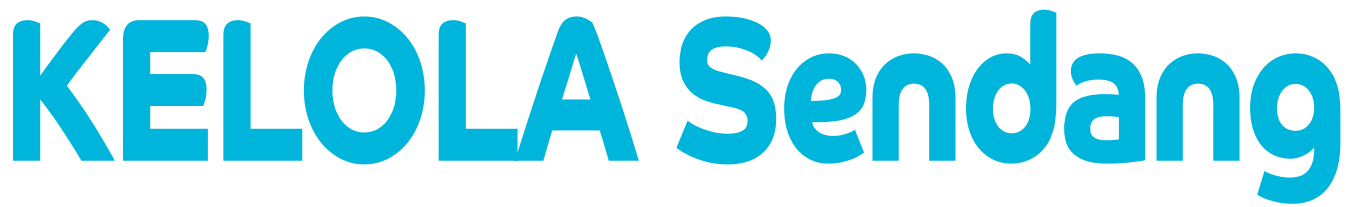

Kemitraan Pengelolaan Lanskap Sembilang Dangku

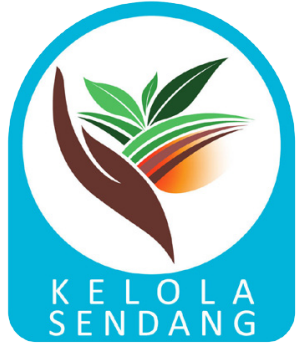

\section{Eksplorasi Potensi Nipah untuk Restorasi Ekosistem dan Mitigasi Perubahan Iklim, Penghidupan Masyarakat Berkelanjutan dan Energi Terbarukan}
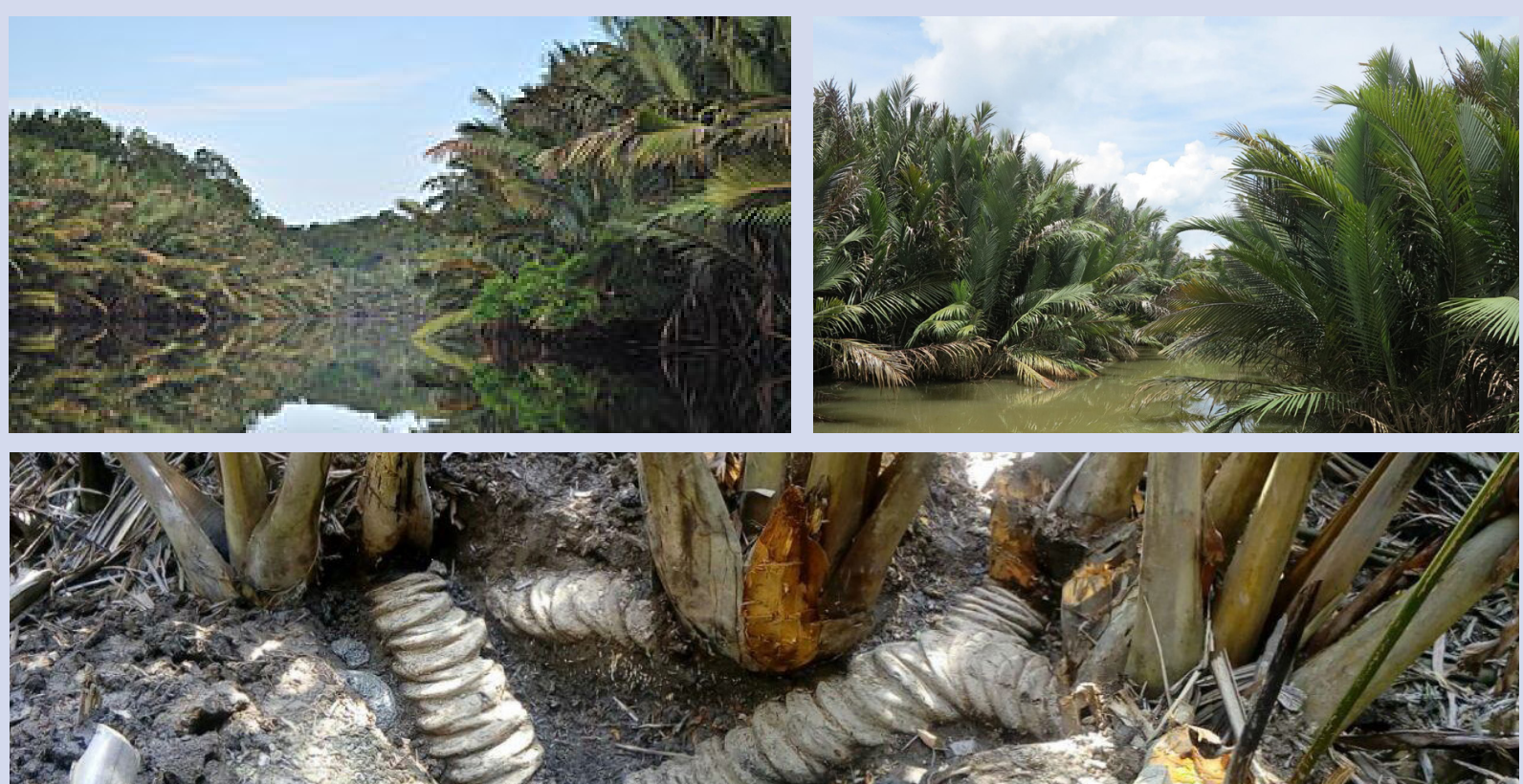

Nipah di Taman Nasional Berbak Sembilang (kiri atas); Nipa tumbuh di muara air payau (kanan atas); Batang bagian bawah nipa yang terlihat (bawah) Foto: ZSL

\section{Pendahuluan}

Nypa fruiticans, yang dikenal sebagai Nipah, adalah spesies asli pohon palem yang tumbuh di pesisir pantai dan muara di Samudera Hindia dan Pasifik. Luasan Nipah meliputi 700,000 hektar di Indonesia, sedangkan di Sumatera Selatan, Nipah merupakan komponen hutan bakau dan meliputi area besar di sepanjang pantai, muara dan riparian dari sungai. Setengah dari ekosistem alami nipah di Sumatera Selatan telah terganggu oleh kegiatan manusia dan membutuhkan upaya restorasi.
Nipah dapat digunakan sebagai salah satu sumber penghasil gula. Hutan alami nipah memiliki potensi untuk menghasilkan penghidupan masyarakat yang berkelanjutan khususnya bagi yang tinggal di kawasan dataran rendah.

Saat ini, nipah telah teridentifikasi sebagai sumber potensi dari energi terbarukan. Getah Nipah yang kaya akan gula dapat digunakan untuk memproduksi etanol sebagai biofuel. Potensi ini mendorong Proyek KELOLA Sendang untuk melakukan eksplorasi dari potensi nipah untuk restorasi ekosistem, mitigasi 
perubahan iklim, penghidupan masyarakat yang berkelanjutan dan energi terbarukan.

\section{Botani and Ekologi}

ypa fruticans adalah satu-satunya jenis palem yang dapat beradaptasi dengan bioma bakau, yang pada umumnya memiliki air payau. Habitat alami dari Nipah memiliki konsentrasi garam 1 dari 9 ppmdengan tipe tanah yang dideskripsikan berlumpur dan kaya akan lumpur alluvial, tanah liat dan humus, dan memiliki kisaran $\mathrm{pH}$ 5. Umumnya memiliki berbagai garam nonorganik, sulfida dari besi dan mangan. Nipah dapat hidup pada temperatur minimum $20^{\circ} \mathrm{C}$ dan maksimum $32-35^{\circ} \mathrm{C}$.

Nypa fruticans beradaptasi dengan baik pada kawasan bakau dengan kandungan garam yang sedang, pada muara yang relatif tenang. Spesies ini dapat mendominasi saluran anak sungai yang bercabang satu maupun banyak, teluk, pasang surut, selama ada gelombang pasang dan arus keluar air tawar.

Nipah umumnya tumbuh subur pada sedimen yang diendapkan oleh proses akresi laut, menciptakan tanah liat, dengan air payau yang mendorong proses sistem anaerobik. Nipah dapat ditemukan di daerah yang lebih dalam dari pesisir selama arus air dapat membawa biji Nipah yang tergenang. Spesies ini dapat mentoleransi gelombang pasang yang jarang, selama tanah tidak mengalami kekeringan yang terlalu lama. Batang horisontal dari Nipah dapat menguatkan tepi sungai dari erosi tanah dan daunnya dengan cepat akan muncul apabila rusak. Selain menghasilkan banyak produk yang
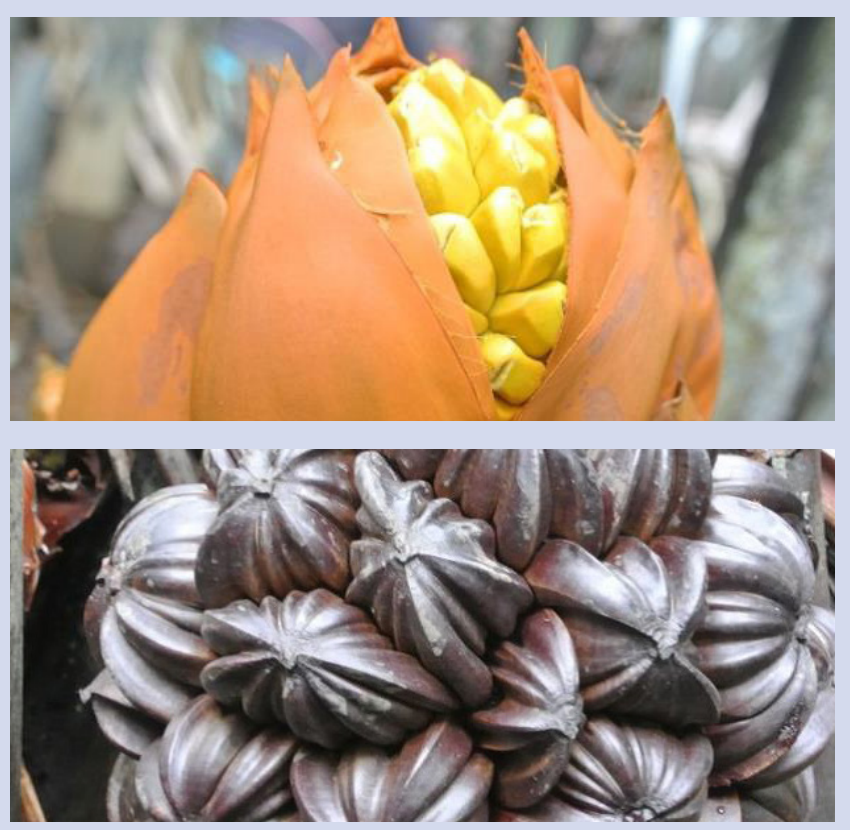

bermanfaat bagi masyarakat, Nipah pun akan secara cepat melindungi lahan setelah badai.

Batang Nipah tumbuh di bawah tanah dan hanya menampakkan daun dan tangkai bunga. Jenis ini dapat mencapai tinggi sampai dengan 9 m (30 kaki). Daun muda muncul di tengah mahkota dan mendorong daun tua sebelum menjadi kering dan jatuh, meninggalkan daun pangkal bulat atau bekas luka. Diameter dari tandan dapat mencapai $75 \mathrm{~cm}$. Mahkota dewasa memiliki 6 sampai dengan 8 daun yang hidup dan memiliki 12 sampai dengan 15 daun pangkal bulat.

Nipah adalah tanaman berumah satu. Bunga Nipah berada di perbungaan bulat dengan bunga betina di ujung dan bunga jantan yang terkulai panjang berwarna merah atau kuning pada tangkai bawah. Bunga Nipah memproduksi kacang berkayu yang tersusun dalam gugus bola sampai dengan $25 \mathrm{~cm}$ di atas satu tangkai tunggal. Kacang yang sudah masak terpisah dan mengapung tersebar melalui arus air. Biji berkecambah melalui pembuahan vivipar (terjadi pembuahan pada saat masih ada di pohon), layaknya spesies bakau lainnya.

Setelah tumbuh dari biji, Nipah menyebar dengan cara pertumbuhan batang bawah yang menjuntai pada media tumbuh dan batang bawah yang terletak di bawah media tumbuh. Dengan demikian, Nipah membentuk tegakan murni yang luas dengan percabangan rimpang yang membentuk dua cabang. Nipah seringkali ada di air payau, membentuk perbatasan yang lebar di luar pinggiran mangrove atau hutan rawa yang berdekatan. Nipah tidak dapat tumbuh pada pantai yang memiliki gelombang besar dan kondisi salinitas yang tinggi
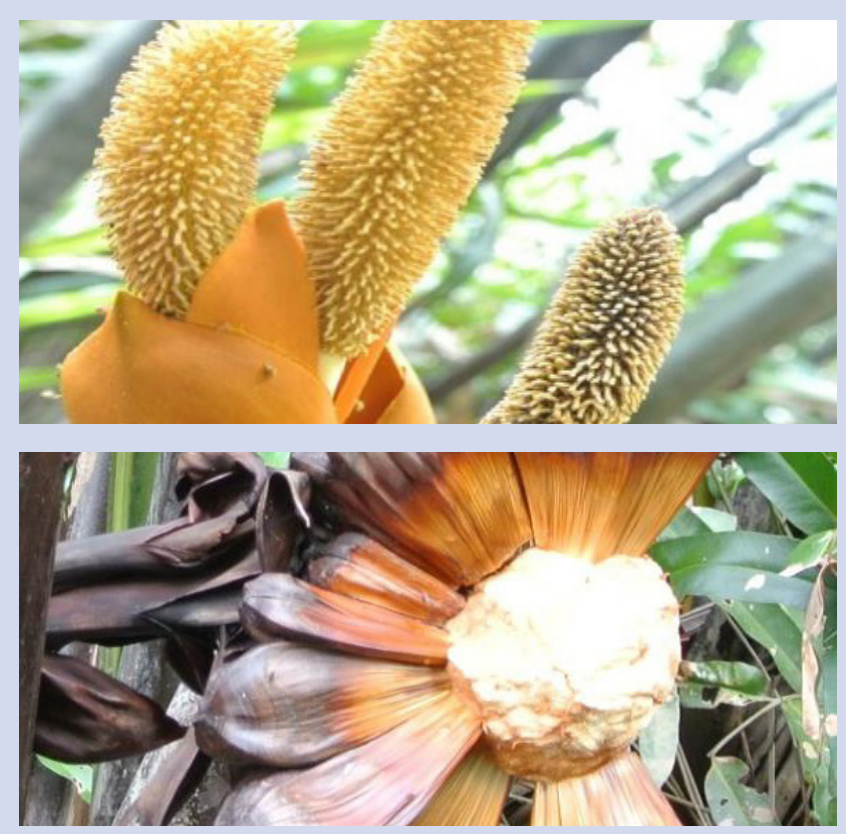

Bunga betina (kiri atas); Bunga jantan (kanan atas); Tandan buah dewasa (kiri bawah); kacang matang yang terpisah dari klaster (kiri bawah). Foto; ZSL. 


\section{Rehabilitasi}

erdasarkan karakteristiknya, dimungkinkan untuk Derehabilitasi kawasan dengan ekosistem air payau dengan Nipah. Kawasan yang telah terganggu akan melakukan regenerasi sebagai hasil dari regenerasi alami. Apabila ditanam dengan biji, Nipah akan secara cepat tumbuh dan memenuhi area dengan pertumbuhan batang bawah yang menjuntai pada media tumbuh dan batang bawah yang terletak di bawah media tumbuh membentuk tegakan murni yang luas.

Nipah dapat ditanam dan ditumbuhkan dari biji, teknik ini telah berhasil digunakan untuk mengembalikan tanah sawah yang memiliki salinitas tinggi. Nipah juga dapat digunakan untuk tambak udang yang sudah tidak digunakan untuk merehabilitasi ekosistem payau.

Di bawah kondisi tersebut, membenihkan biji nipah dapat dilakukan di lubang kecil yang dikubur. Tanpa menguburkan biji, biji mudah terganggu oleh hama tikus maupun banjir. Waktu penanaman biasanya dilakukan pada musim kemarau dimana terdapat tanah yang cukup lembab dan dalam. Umumnya, jarak yang digunakan dalam penanaman adalah $2 \times 2 \mathrm{~m}$. Satu tahun setelah penanaman, benih dapat mencapai tinggi $50 \mathrm{~cm}$, dan pada tahun ketiga akan mencapai $2 \mathrm{~m}$. Dikarenakan percabangannya yang membentuk dua cabang dan batang tumbuh di bawah tanah, rumpun yang tebal terbentuk pada saat Nipah berumur 5-6 tahun.

Di Malaysia, kebun Nipah telah dibangun dengan menggunakan benih yang disiapkan di dalam polybag menggunakan biji superior penghasil getah. Perusahaan berharap dengan perkebunan ini dapat meningkatkan produksi getah untuk gula dan produksi makanan lainnya, atau sebagai sumber produksi etanol sebagai biofuel.

Hutan Nipah yang direhabilitasi dapat menyerap karbon dengan jumlah yang besar, dan juga berfungsi sebagai penyerap dengan penyimpanan karbon baik di atas maupun di bawah tanah (above ground carbon dan below ground carbon). Diestimasikan hutan Nipah memiliki 4 kali lipat karbon dari hutan dataran rendah. Selain itu, Hutan Nipah menyediakan tempat yang baik untuk pemijahan ikan, krustasea dan moluska.
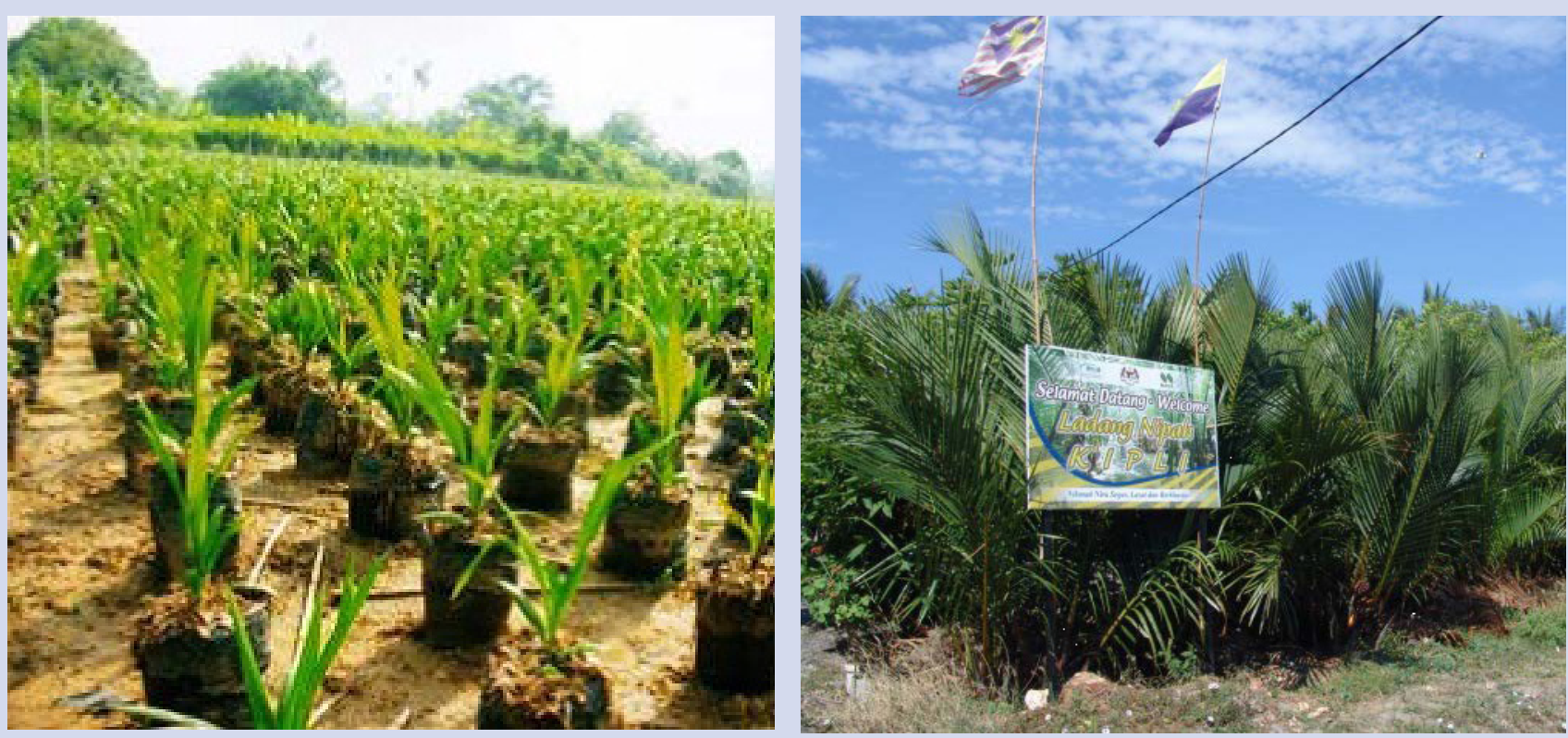

Benih Nipah disiapkan untuk penanaman (kiri); Kebun Nipah dibangun untuk produksi bioethanol - Kedah, Malaysia (Pioneer Vaccination Biotech Corporation Sdn. Bhd.) (kanan). Foto: ZSL

\section{Penggunaan Tradisional}

$\mathrm{N}$ ipah telah digunakan secara tradisional oleh manusia untuk berbagai macam tujuan. Selama ini, nipah telah digunakan untuk bangunan rumah. Daun panjang menyirip dapat berfungsi sebagai bahan atap rumah. Di Filipina, Malaysia, Indonesia dan Thailand bahan pembuat atap yang juga memiliki nama lokal 'shingles', 'pawid' atau 'attap', adalah sumber penghasilan lokal yang signifikan.

Helai daun dan pelepah digunakan untuk pembuatan sapu, keranjang, tikar, topi, payung, jas hujan, tali dan bungkus rokok. Nelayan lokal biasanya menggunakan daun untuk pelapis, dan menggunakan batang bawah untuk menebar jaring. Dahulu, garam diekstraksi dari Nipah, sedangkan daun kering, pangkal pelepah daun, 


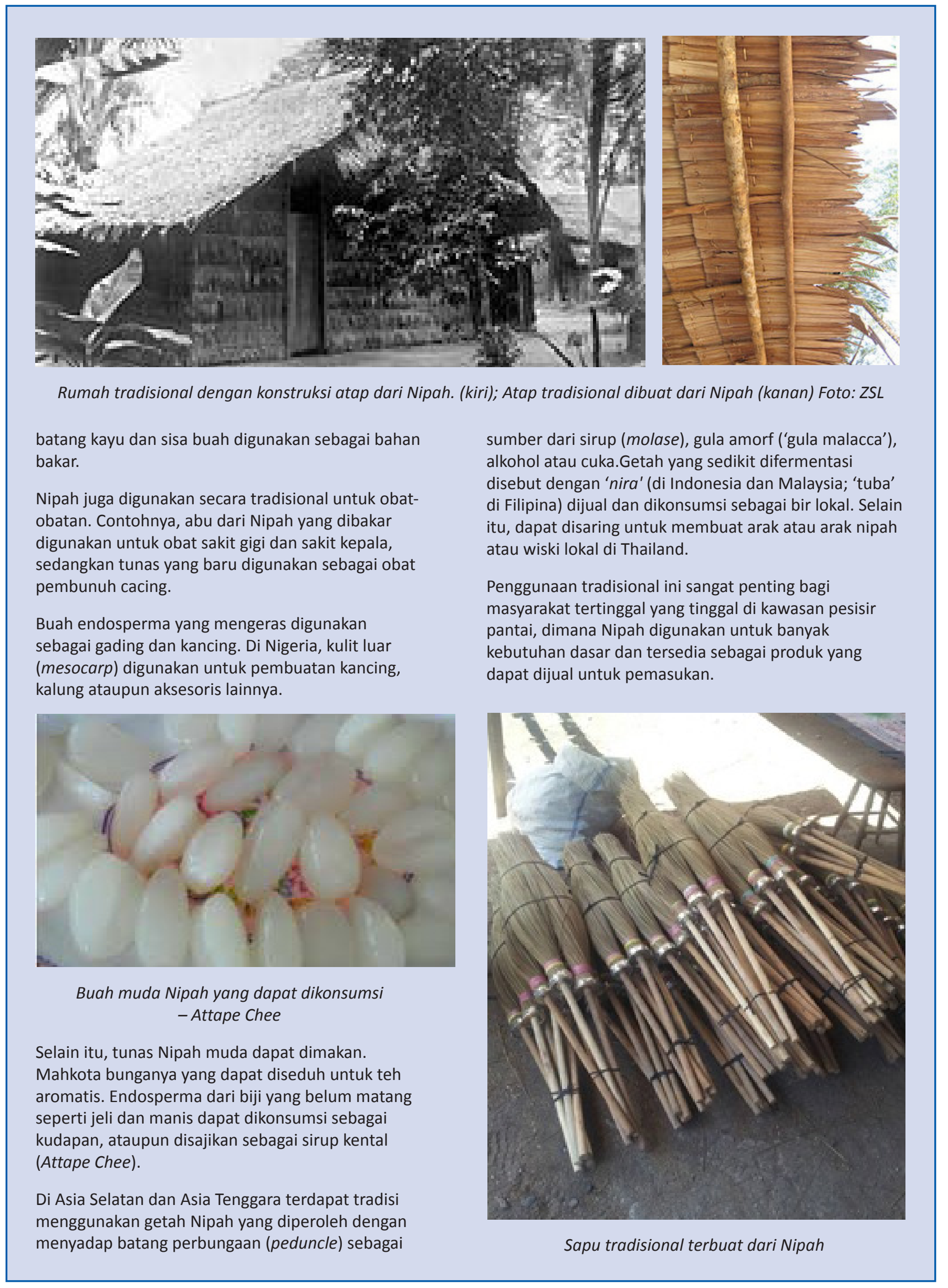




\section{Modernisasi Produksi Produk Tradisional untuk Penghidupan Berkelanjutan}

\section{Gula Nipah dan Produk Pangan Lainnya}

D alam beberapa tahun terakhir, terdapat minat baru dalam memproduksi gula dan bahan pangan lainnya dari Nipah. Hal ini menyebabkan modernisasi metode untuk produksi, pengolahan dan pemasaran. Minat ini dikaitkan dengan manfaat kesehatan dari Nipah yang dirasakan, dan dapat diklasifikasikan sebagai gula alternatif dan merupakan gula organik yang lebih sehat sebagai substitusi dari gula sintetis untuk pengidap diabetes, berat badan berlebih dan bagi orang-orang yang sadar akan pentingnya kesehatan. Gula Nipah dapat digunakan sebagai pemanis dan bahan pangan maupun produk kembang gula seperti kue kering dan makanan lokal setempat. Dengan peningkatan teknis yang sederhana dapat menghasilkan produk yang lebih baik.

Inovasi sistem pengumpulan Nipah telah dilakukan. Misalnya, kantong fleksibel atau plastik steril yang biasa digunakan untuk mengumpulkan getah. Metode ini meminimalisir paparan udara dan kontaminan terhadap getah dan memungkinkan pengumpulan yang higienis sesuai dengan persyaratan keamanan pangan.

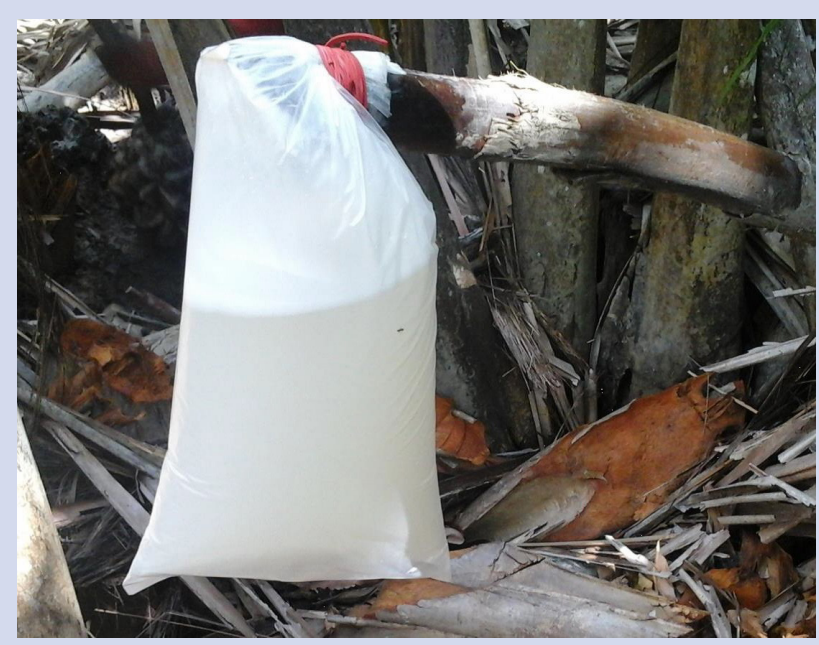

Getah Nipah dikumpulkan dengan wadah plastik. Foto : ZSL

Selain itu, terdapat peningkatan pada peralatan pengolahan yang digunakan untuk pendinginan getah Nipah dalam menghasilkan gula. Getah Nipah yang terkumpul direbus atau dimasak dengan menggunakan teko uap, menggantikan proses pemanasan secara langsung dengan wajan terbuka yang dilakukan secara tradisional. Dengan inovasi ini,hangus saat memasak dapat dihindari.

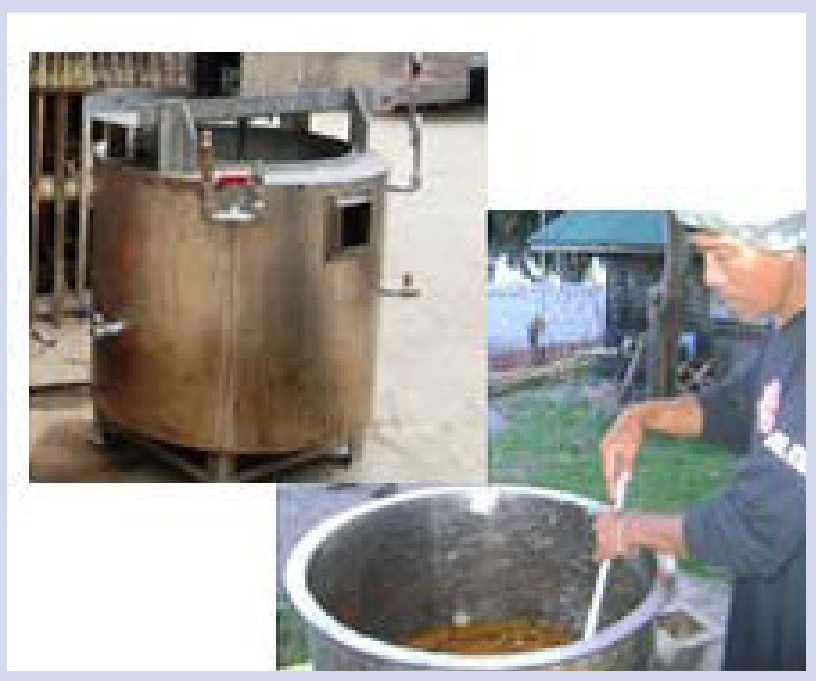

Modifikasi teko uap (fire-tube-steam-jacket kettle)

Penghasilan dari pengumpulan dan pengolahan getah Nipah dapat melebihi mata pencaharian lainnya. Setidaknya terdapat 4850 petani $(60-70 \%$ dari total populasi) yang memanen getah Nipah secara lestari dari luas 3,200 ha. Nipah telah dipanen secara lestari lebih dari 200 tahun tanpa ada penurunan angka produksi. Potensi produksi ini serupa dengan Hutan Nipah di Sumatera Selatan.
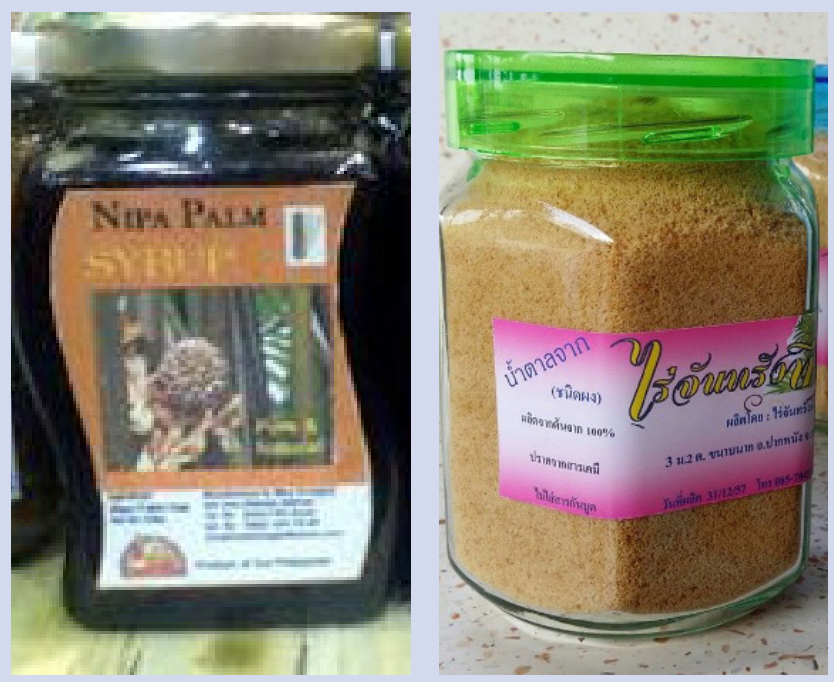

Sirup dari Nipah (kiri); Tebu dari Nipah (kanan) 


\section{Minat Terbarukan pada Nipah oleh Industri Pariwisata}

Pariwisata merupakan salah satu bidang ekonomi terbesar dan tercepat di negara Asia Tenggara. Terdapat permintaan untuk kebutuhan akomodasi tradisional atau pedesaan, rumah makan dan pondok di pantai yang dibangun dengan bahan tradisional. Akibatnya, permintaan untuk bahan atap dan panel dari bahan daun Nipah meningkat. Nipah merupakan sumber yang terbarukan dan dapat tumbuh dengan cepat, lingkungan alam mendapat manfaat dari pengelolaan Nipah yang lestari untuk menyediakan pasok pembuatan atap yang berkelanjutan bagi industri pariwisata yang sedang berkembang. Hal ini juga berdampak baik pada penyediaan lapangan kerja baik dalam produksi atap maupun dalam penyediaan fasilitas bagi wisatawan domestik maupun mancanegara.

Ekowisata didorong untuk memberikan nilai tambah pada kawasan lindung, dan untuk membangun kesadaran akan pentingnya jasa lingkungan yang disediakan oleh kawasan lindung. Mempelajari pentingnya lingkungan dan ekonomi tradisional dari tumbuhan, seperti Nipah, dapat membangun dukungan lokal dan internasional untuk dunia konservasi.
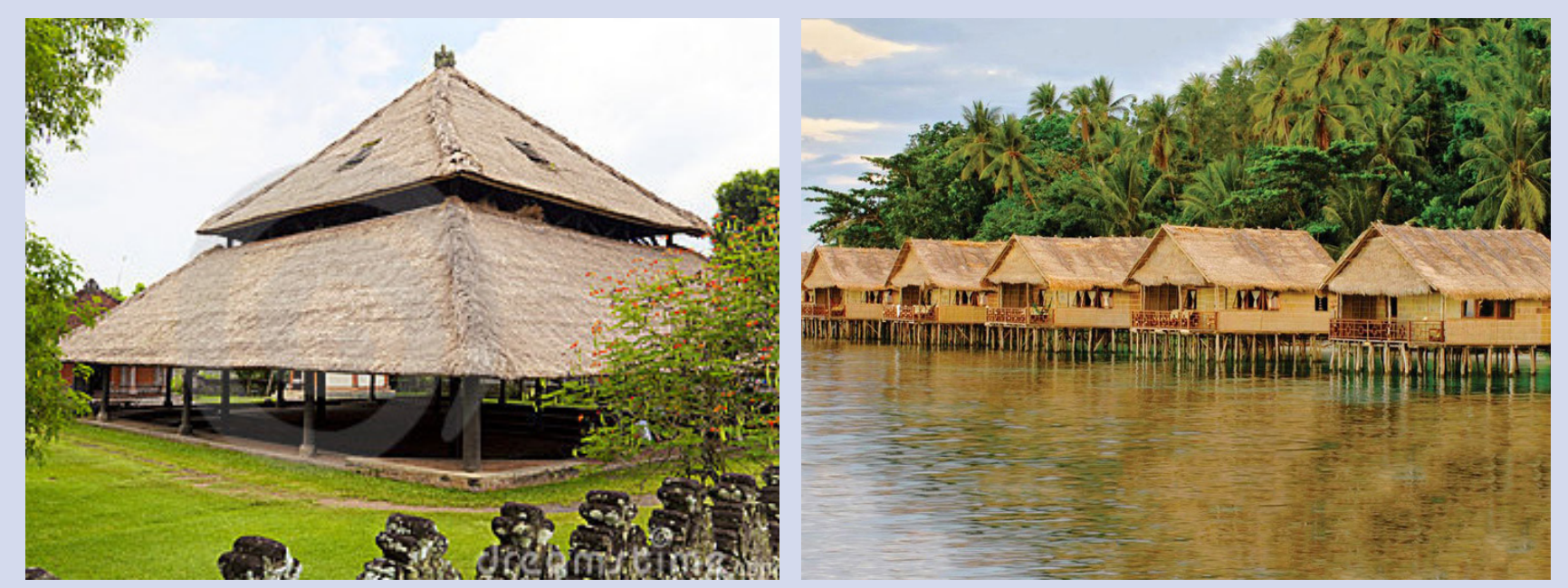

Bangunan di Bali dengan menggunakan atap dari Nipah (kiri). Pondok di Papua dengan atap dari Nipah (kanan).

\section{Eksplorasi Potensi Biofuel dari Nipah}

Dalam memproduksi biofuel, faktor terpenting adalah hasil panen dari jenis tumbuhan yang digunakan.

Tebu, kelapa sawit dan singkong telah memberikan hasil produksi yang baik. Namun, terdapat salah satu spesies palem tropis yang kurang dimanfaatkan (Nypa fruticans), yang menjanjikan dalam hal produksi etanol di daerah tropis. Habitat dari Nipah adalah tepi sungai di kawasan pasang surut dan lahan basah air payau, dimana batang pohon Nipah tumbuh di bawah tanah, dan daunnya dapat mencapai tinggi $9 \mathrm{~m}$. Daun besar Nipah dapat menyerap dalam jumlah besar fotovoltaik dan fotosintesis karbon dioksida (CO2) di siang hari, dan menangkap karbon dioksida di dalam getah yang kaya akan gula.

Penelitian terbaru menunjukkan bahwa Nipah memiliki potensi yang signifikan untuk memproduksi biofuel dalam bentuk bioetanol. Potensi ini diilustrasikan pada Gambar di bawah dari Center for International Forestry Research (CIFOR). Berdasarkan gambar, Nipah berpotensi menghasilkan dua kali jumlah etanol per ha dari tebu, dan empat kali dari jagung. Dengan demikian, hasil penelitian ini menunjukkan manfaat lain yang lebih luas cakupannya: (i) ekonomis, (ii) siklus tahunan dan membutuhkan input rendah (sedikit atau tidak ada bahan kimia yang digunakan), (iii) melindungi dari pasang surut, topan dan tsunami, (iv) meningkatkan keanekaragaman hayati (baik daratan maupun perairan), (v) ramah petani kecil, (vi) getah dapat dikumpulkan tanpa memanen biomasa lainnya, dan (vii) dapat menjadi bagian dari sistem produksi pangan (memproduksi gula dan bioetanol). Selain itu, terdapat temuan penelitian yang menunjukkan Nipah berfungsi sebagai penyaring alami ion logam berat dari larutan dan menyimpannya di dalam tanaman. 


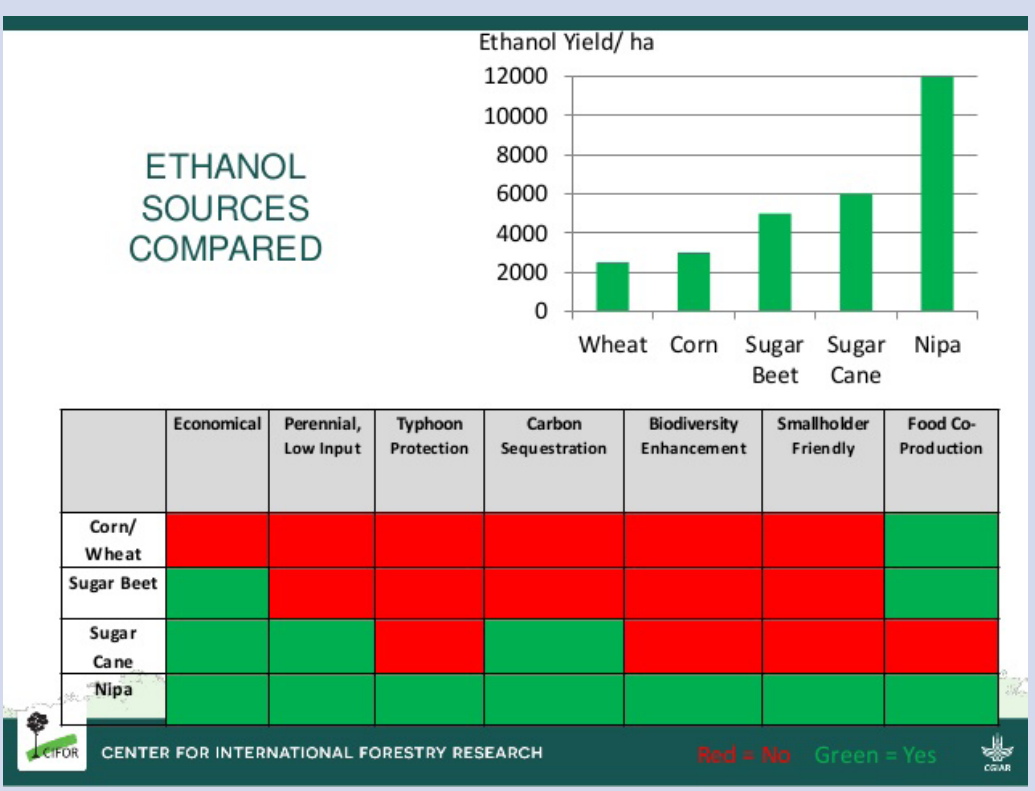

Diagram Alur Produksi Etanol di bawah ini dengan jelas menggambarkan keuntungan bahwa pengolahan getah Nipah telah melebihi dari bahan baku lainnya. Proses pengolahan yang lebih pendek dan membutuhkan sedikit input tenaga kerja dan energi. Meski tidak diilustrasikan, pengolahan getah Nipah juga jauh lebih efisien dibandingkan dengan yang dibutuhan untuk memproduksi bioethanol dan kelapa sawit.

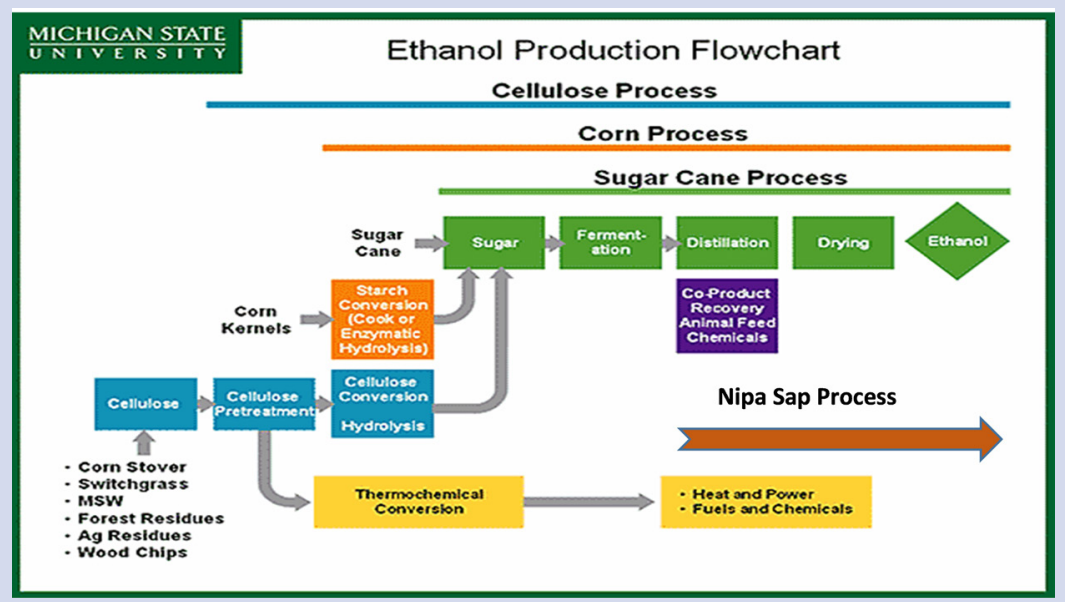

Getah kaya gula dari Nipah adalah satu dari sedikit sumber biofuel alami yang bebas racun dan menghasilkan bioetanol. Dibutuhkan sekitar 13 liter getah Nipah kaya gula untuk menghasilkan sekitar 1 liter bioethanol. Residu dari getah Nipah yang digunakan menghasilkan produk sampingan yang dikenal sebagai Captured Liquid Carbon Dioxide (CO2) (CLCD) yang dapat digunakan sebagai Pupuk Bio Organik. Produksi Nipah yang baik dapat menghasilkan antara 12.000-20.000 liter etanol per hektar per tahunnya, sedangkan jagung dan tebu hanya bisa menghasilkan 6.000 7.000 liter. Getah Nipah dapat dikumpulkan setiap harinya dari pohon tanpa merusak pohonnya, sehingga memberikan lapangan pekerjaan tetap bagi para pekerja. Kondisi ini diilustrasikan di Thailand Selatan, dimana getah Nipah sudah dipanen lebih dari 200 tahun dari lokasi yang sama tanpa mengurangi tingkat produksi maupun merusak tegakannya.
Pada ekosistem rusak yang membutuhkan restorasi, Nipah dapat dengan mudah ditanam dari biji atau benih. Nipah dapat disadap 4 tahun setelah penanaman, dan dapat terus dipanen lebih dari 50 tahun, regenerasi dari batang dan batang bawah yang ada di bawah tanah. Penyadapan Nipah intensif merupakan kegiatan yang menjanjikan dalam menciptakan pekerjaan di pedesaan. Diperkirakan bahwa penyadap getah yang terampil dapat mengumpulkan stok etanol untuk mendukung produksi komersil biofuel serta produksi pupuk bioorganik CLCD, sementara memperoleh pendapatan yang layak melampaui upah minimum lokal. Penggunaan pupuk bio-organik CLCD oleh produsen pertanian di dalam lanskap dapat mengurangi jumlah pupuk kimia yang diserap oleh lingkungan.

Di Filipina, getah Nipah dapat diolah pada pabrik pengolahan untuk memproduksi bioethanol dari tebu. Adanya getah Nipah mengisi kapasitas pabrik pengolahan tebu yang kurang dimanfaatkan dan mengurangi biaya rata-rata dari produksi bioethanol dengan Nipah yang diolah dengan biaya lebih rendah dibandingkan tebu.

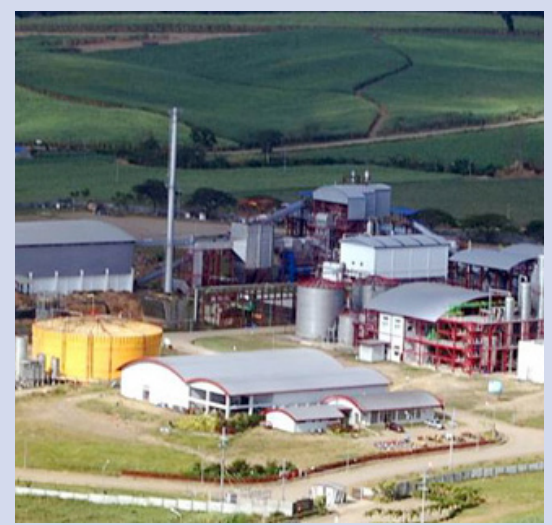

Pengolahan untuk memproduksi bioethanol dari tebu, digunakan untuk mengolah getah dari Nipah.

Selain itu terdapat destilasi yang lebih kecil dan dapat digunakan oleh koperasi untuk memproduksi bioethanol untuk penggunaan lokal, seperti generator dan motor yang disesuaikan untuk penggunaan 
bioethanol. Hal ini penting untuk desa yang terpencil dan tidak terhubung dengan jaringan listrik dari pemerintah, karena mahalnya pengecer gas dan solar.

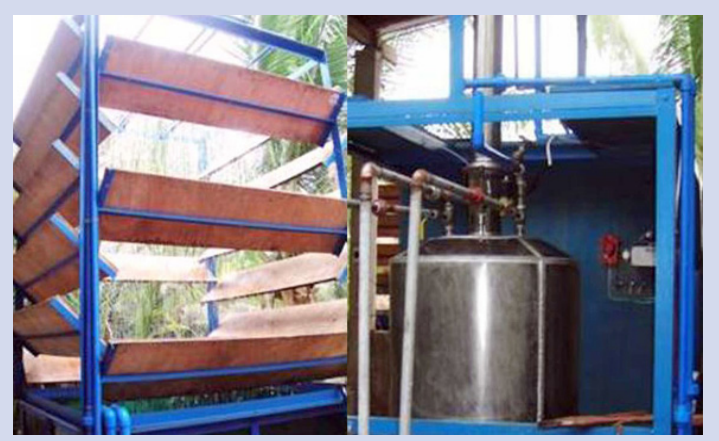

Pengolahan untuk memproduksi bioethanol dari tebu, digunakan untuk mengolah getah dari Nipah.

\section{Perlindungan dan Restorasi dari Ekosistem Nipah yang Rusak}

Diperkirakan sekitar 50\% ekosistem Nipah di dataran rendah Sumatera Selatan telah rusak dan membutuhkan restorasi. Restorasi membuka kesempatan tidak hanya untuk memperbaiki lingkungan dan menyerap karbon, namun juga menghasilkan pendapatan dan mata pencaharian bagi masyarakat yang tinggal di zona pasang surut. Apabila berhasil, dapat menjadi solusi bagi kedua belah pihak untuk keanekaragaman hayati yang dapat ditingkatkan sekaligus berkontribusi pada penghidupan pedesaan yang lebih berkelanjutan. Proyek diharuskan mengeksplorasi potensi lingkungan dan manfaat penghidupan serta potensi trade-off dari ekosistem Nipah yang rusak.

\section{Referensi}

Bamroongrugsa, N., Buachum, S., Purintavarakul, C. (2008). Nipa Palm (Nypa fruticans Wurmb.) cultivation in salt affected paddy fields. J. Trop. Plants Res. 1: 93-102.

Bamroongrugsa, N. and Purintavarakul, C. (2008). Growing nipa palm for restoration of abandoned shrimp ponds. Wetl. Sci. 4(2): 91-95.

Biofuel Academy (2017). Fermentation of Nypa Palm to Form Ethanol. http://biofuelacademy.org/web-modules/process/ fermentation/fermentation-of-nypa-palm-to-form-ethanol/

Giesen, W., Wulffraat, S., Zieren, M. and Scholten, L. (2006). Mangrove Guidebook for Southeast Asia. Part VIII: Palms, Cycads and Pandans. FAO and Wetlands International, Bangkok.

Hamilton, L.S. and Murphy, D.H. (1988). Use and management of nipa palm (Nypa fruiticans, Arecaceae): a review. Econ. Bot. 42 (2): 206-213.

Hidayat, I.W. (2015). Natural production potency of nipa (Nypa fruticans) sap as production commodity for bioethanol. Pros. Sem. Nas. Masy. Biodiv. Indo., Volume 1, Nomer 1, Maret 2015, p.109-113.

Jian, S., Ban, J. and Yan, H. (2010). Low genetic variation detected within the widespread mangrove species Nypa fruticans (Palmae) from Southeast Asia. Aquat. Bot. 92: 23-27.

Marris, E. (2006). Sugar cane and ethanol. Drink the best and drive the rest. Nature, 444: 670-672.
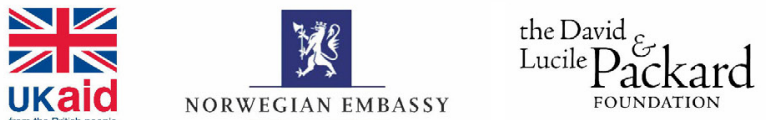

UKaid

NORWEGIAN EMBASSY
Matsui, N., Bamroongrugsa, N., Mormume, H. and Okimori, Y. (2011). Nipa Palm: A potential alternative source for bioethanol. Research Paper 14th Mangrove National Seminar. Thailand

Matsui, N., Okimori, Y., Takahashi, F., Matsumura, K. and Bamroongrugsa, N. (2014). Nipa (Nypa fruticans Wurmb.) Sap Collection in Southern Thailand: I. Sap Production and Farm Management. Environ. Nat. Res. 4 (4): 75-88.

Ridho, R.M., Sundoko, A. and Ulqodry, T.Z. (2006). Analisis perubahan luasan mangrove di Muara Sungai Banyuasin, Sungsang dan Upang Provinsi Sumatera Selatan Menggunakan Citra Satelit Landsat-TM. Jurnal Pengelolaan Lingkungan dan SDA 4(2): 11-18. [Indonesian]

Tamunaidu, P., Matsui, N., Okimori, Y. and Saka, S. (2013). Nipa (Nypa fruiticans) sap as a potential feedstock for ethanol production. Biom. Bioe. 52: 96-102.

Tamunaidu, P. and Saka, S. (2011) Chemical characteristics of various parts of nipa palm (Nypa fruticans). Ind. Crop Prod. 34 $1423-1428$

Tamunaidu, P. and Saka, S. (2013). Comparative study of nutrient supplements and natural inorganic components in ethanolic fermentation of npa sap. J. Jpn. Inst. Energy 92(2): 181-186.

Tsuji, K., Ghazalli, M.N.F., Nordin, Z., Khaidizar, M.I., Dulloo, M.E. and Sebastian, L.S. (2011). Biological and Ethnobotanical Characteristics of Nipa Palm (Nypa fruticans Wurmb.): A review: Sains Malays. 40 (12): 1407-1412.
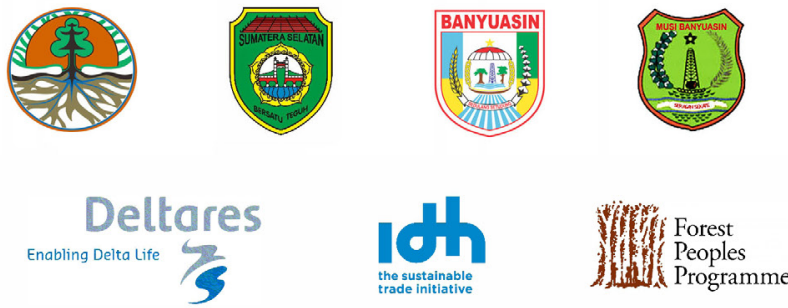

This material has been funded by UK aid from the UK government; however the views expressed do not necessarily reflect the UK government's official policies. 